\title{
The World's Monetary and Payments Situation *
}

\author{
by Dr. Otmar Emminger **
}

I was asked to make some introductory remarks on the world's monetary and payments situation. I think that is a subject which fits very well under the general heading of this meeting, namely Facing Risks and Uncertainties, because there was never a time before when there were so many risks and uncertainties in the international monetary and payments system.

I cannot possibly deal with all aspects within the time allotted to me, which is twenty minutes, so I have to ask your indulgence if I may be leaving out a lot of important points and I hope that then during the discussion period you will take them up. I shall mainly deal with two dominant influences which in the recent past, and also at present, have had a large impact on the world payment situation, namely on the one hand the oil shock, and on the other hand the impact of high American interest rates on exchange rates and on the European economic situation. Now the two aspects have been very curiously linked together : just a few days ago, the Monetary Committee of the Common Market, of which I was in the past a member for over twenty years myself, put a Memorandum on the table of the EEC Economic Ministers in preparation for the Summit Conference in Ottawa, and among the interesting conclusions there was one which says that the thirty-five to forty per cent appreciation of the dollar against the currencies of the European Monetary System over the past twelve months, has had an effect on import prices of these countries comparable to that caused by a big oil price increase ; and the French Finance Minister Delors put it even more succinctly into the formula : The US high interest-rates policy and its impact on the dollar has had the effect of a third oil-shock.

So here we have a very interesting proposition which we have to look at in the end. Before doing that, I want to say a few words on where we stand with the payments impact of the second oil-shock. It's a very appropriate moment to do that because as you know, the situation in the oil market has changed greatly - we have now an oil glut and that gives us some breathing space; although I must warn here that this is not necessarily a lasting condition. We get very different advice and predictions from the various experts. Most of them say Well, this easing of the oil situation may last for two or even three years. But just recently a very well-known expert on this

* Address Given at the General Assembly of Members, The Geneva Association, at London, England, on Wednesday, July 8, 1981.

** Former President of the Deutsche Bundesbank, Frankfurt am Main. 
question, Mr. Schlesinger, former Secretary of Defence and of Energy in the United States, came out with the statement that the next oil-crunch or oil-crisis may already be around the corner, if we don't take precautions.

We have seen that, contrary to the very alarmist forecasts which we had one or two years ago, the international monetary system has, at least up to now, been able to cope surprisingly well with the second oil-shock. I cannot go, because of reasons of time, into the details, except by saying that this is true in a global way ; it's also true in a global way as concerns the international banking system. There is no fear now of a breakdown, of a chain reaction. What, however, is still there in the international payments situation, are problems of individual countries, especially developing countries, and you know, of course, that most of the deficits and most of the international indebtedness is concentrated within a group of ten or twelve major deficit countries. Here you have to look at every single case in a different way because the problems are very different. The two major debtor countries are Brazil and Mexico, and Mexico is itself an oil-exporting country, and has quite different problems from Brazil.

There are some cases where the banks have run into difficulties, where they have had too high country risks - I just mention the cases of Turkey and Poland. Perhaps you'll permit me to make one short remark on the Polish situation because with hindsight $I$ think it can now be said that it was a mistake that last year the Western countries continued lending to Poland without asking for some adjustment programme. Here it was visible that something was lacking in this relationship, namely the IMF, who in such cases usually is the guardian of balance of payments discipline. But since Poland is not a member of the IMF, there was really nobody to look after that side. The postponement of the day of reckoning in the Polish case by one year, I think, will have to paid dearly. I don't think only in the financial sense but also in the political sense, because I'm afraid that the deterioration which in the meantime has taken place in the overall economic situation is really risking to bring the whole liberalisation in the political field down again.

Don't be too much afraid about the very high global figures for the deficits and the total external debt of the non-oil developing countries. The IMF is usually putting forward very high figures like 82 billion dollars total deficits on current account last year and nearly 100 billion dollars probable deficits of the developing countries this year - these are very misleading figures and really don't give the right information on the situation, because they don't take account of the official transfers into the developing countries which don't necessarily lead to new indebtedness. There is, however, one aspect which I should mention here, because there is a direct link here to American high interest rates, and that is the enormous increase in the interest burden of a number of developing countries. There is an estimate by Morgan Guarantee to the effect that in 1981 the interest burden of the twelve major deficit countries in the developing group will be around 26 billion dollars, and that is in relation to their export proceeds at least double of what it was in the second half of the seventies. We know there are some countries where interest burden plus oil bill together preempt more than one half of their export proceeds. It is the more remarkable that in spite of this very high burden both from oil and from interest rates, this group of developing countries as a whole, up to now at least, has managed better in terms of produc- 
tion and trade than the industrial countries. Last year they increased their overall production by 4 to 5 per cent while the industrial world achieved only a real growth rate of 1 to $1 \frac{1 / 2}{2}$ per cent, and also their foreign trade has held up better than that of the industrial countries.

Just a word on the payments problems of the industrial world, because there we have seen over the last few years a completely new line-up, completely different from what it was after the first oil-shock. Remember after the first oil-shock it was Germany, Switzerland and some other European countries which had the strong currencies. This time we have three strong currencies and it's the dollar, the yen and the pound sterling - the last one potentially at least. I include the pound sterling in spite of the recent fall in the exchange rate of the pound, because my measure of the strength or weakness of a currency is mainly the current account of the balance of payments, and it is these three countries that have either a surplus or at least an equilibrium in their current account balance of payments. With Britain of course it's mainly the effect of North-Sea oil. But with the other two strong countries it's different causes, while all the other industrial countries, or pratically all the others, especially on the European continent, are deeply in the red in their current account. I may just insert here one quite important consideration, namely: what really influences exchange rates ? Of course many influences are there, but by far the most important up to now has always been the balance of payments on current account. I could exemplify that with the example of the dollar, of the yen, etc. but $I$ just put it forward as a proposition which may be questioned. The current account position is in the longer run more important than interest rate differentials. We have seen in the German case that the current account balance was several times as important as the capital balance, and so it is with some other countries too.

I have no time to explain to you the very complicated reasons why the D-Mark in particular has fallen from grace, as some people have said, while it was in the previous twenty years a strong currency. West Germany has at present the largest deficit on current account of all countries. This raises a very important question, namely: how can countries who are so deeply in deficit in their current account balance of payments, how can they turn around their balance of payments again ? Here we could ask How did the United States manage? because in 1977-78 they were the chief deficit country on current account of the world economy ; within one and a half years they turned it around. And Japan was the chief deficit country of the world economy in 1979 and in the first half of 1980, and they turned it around within one year.

Now it would be very tempting to go into these spectacular cases in some detail. But I have to limit myself to some quick conclusions, namely : We cannot imitate the Japanese method of turning the situation around, or at least only partially, for various reasons. We have probably to imitate more the United States. And what was the United States' method of getting their current account reversed so quickly? Well, it was really a combination of an under-valued dollar together with an economic stagnation or even temporary recession at a time when the rest of the world was still in an economic upturn, so that there was a big difference in the cyclical position favourable to the dollar. The combination of the two factors explains not entirely, but to a large extent the turn-around in the United States payments position. One would have to add 
some structural factors, like agricultural exports, high income from American oil multis, etc.

My conclusions for the German position are as follows : first, we have now a grossly undervalued D-Mark exchange rate, but we will have to continue for some time with an undervalued D-Mark exchange rate just as the dollar was grossly undervalued for several years. This implies a great risk for us because it means, of course, import of inflation, and we have to work very hard in order to prevent this import of inflation over the undervalued exchange rate to become too strong. That is why $I$ have always supported the Bundesbank in as strict a monetary policy as possible.

The second conclusion is that Germany has no chance of getting back into equilibrium again except through an export-led expansion, that is to say one has to wait until the rest of the world economy turns upward again, and only then Germany can follow. It will no longer be a locomotive, but rather a "caboose", following behind for some time. With such a policy we have a chance of turning the balance-ofpayments situation definitely around within one or one and a half years.

I want also to say a few words on the United States position. You know that the present American policy is relying chiefly on two pillars : one is supply side economics, the other is monetarism ; occasionally one has to add a third one which is the theory of rational expectations. I don't want to talk about this policy-mix and all that because I am sure that my friend Mr. Friedman will talk about it in a much more expert way. American monetarism is different from German monetarism, and is different also - as far as I can judge it - from British monetarism. Anyway I can just give you very briefly the difference between the German kind of monetarism and the American kind, because that explains part of the unfortunate influence of American monetarism on the world's interest rates and exchange rates. We in Germany have introduced a practical monetarism since 1974 by publishing monetary targets - we were the first central bank to do this, so we've had some experience with that problem. Our monetary policy differs in two respects from present American monetarism : First, we have always been very pragmatic as concerns the operational technique or procedures; we have never claimed to be able to keep the money volume precisely on track from month to month or even from quarter to quarter, and we also don't think that this is necessary - it's impossible and it is not necessary, provided that the money volume is kept on track in the medium term.

And we were, and that is very important, never under the pressure of public opinion to keep on track from month to month, or as sometimes in the United States they are under pressure to keep on track from week to week which is simply ridiculous. In my view they should never have published any weekly figures. Why are the American monetary authorities under that public pressure ? Because they have not yet fully established their credibility, and in order not to lose their credibility they believe they must try to keep to their money-target over short periods, and as money statistics will go up and down during these short periods for technical reasons, there will always exist here a source of great volatility.

There is a second difference between our German kind of monetarism and the American kind, namely that we have never believed that monetary control by itself is a sort of cure-all, or as someone called it, a " magic incantation" which by itself will 
bring wage and income developments into line, which will establish a stability irrespective of what is being done on the fiscal side. On the contrary, we have always added to every published target one sentence, namely that we cannot reach our goal without the help of a corresponding fiscal policy and without the help of a reasonable wage and price policy. While in the United States at present there is a complete "handsoff " policy as concerns wages, and there is at least one school in the present American monetarism which says fiscal policy doesn't matter very much; that's the Milton Friedman school and I had myself some controversies with him at international meetings on this particular point. Anyway, it is important to realise that looking at the very short-term movements of money volume statistics and reacting in a hectic way to them explains partly this volatility of interest rates, and as relative interest rates have a great short-term effect on some exchange rates, it explains also the high volatility of exchange rates. It is a statistical fact that we have never before had in monetary history such a volatility both in short-term interest rates and in exchange rates as we have had since the beginning of 1980 - at least in the relation between the dollar and D-Mark, because the D-Mark is particularly sensitive to these relative interest rates being the second reserve currency, etc. There are also special reasons why interest rates in the United States at the present time have to be relatively higher than formerly both in nominal and real terms. So we have two facts : a relatively high level of interest rates and very volatile interest rates around this level.

The question is what really will the Europeans achieve with their complaints? You have perhaps seen in the newspapers that they have already toned down a little bit and for very good reasons, and there will not be much of a quarrel at the forthcoming Summit Meeting, because the Americans have good answers to these European complaints. First they will say that we have very high American interest rates because we have also a very high inflation rate, and in particular very high inflation expectations. The second reply which they will give and have always given is: we cannot change our interest rate policy because we don't have any deliberate interest rate policy. They have a quantitative monetary target and interest rates will just be the result of the markets. So when you have no interest rate policy you cannot change it. And the third answer as concerns the very disturbing volatility of interest rates will be (as has been said by their leading monetarists in the Administration) : we ourselves deeply deplore this volatility, but cannot help it ; and they put the blame on two things : first, the operating techniques of the Federal Reserve, and you know Central banks are always the whipping boy whenever anything goes wrong, and secondly on the insufficient credibility of the present monetary policy. So they say : Only if the Federal Reserve keeps a very tight monetary policy will inflation expectations be broken and will interest rates go down, and therefore - they say - the stricter the policy is now, the sooner we will get the turn-around to lower interest rates.

Now I should draw just a few conclusions from this situation : first, in view of the operating procedure which I just mentioned very briefly, I think it is completely impossible to forecast short-term movements of interest rates in the United States. Over the last six months, all American forecasts and predictions on their interest rates were wrong, including those by the President himself.

The second conclusion which $I$ have drawn from this situation is that in the medium term interest rates certainly will be influenced by inflation rates, and as I 
foresee a rather fast down-turn in American inflation rates in the medium term, I am also relatively optimistic that interest rates will have a downward tendency, however with always being interrupted by short-term up and down movements ; this cannot be helped in the American system.

And the third conclusion is that I am very skeptical about this hectic reaction to short-term money supply figures. I think, however, we cannot but accept this Americantype policy because they think it is necessary in order to establish credibility and, as we are vitally interested in the success of their stabilisation policies, I do not think that anybody should dare to advise them how they should react - they have to go through that and we have to go through that with them. It is a high cost we all have to pay in order to re-establish stability in the world, because stability in the world will not be re-established except if the Americans will have success in their fight against inflation.

Just a very short last point : you certainly have seen in newspapers that there is another European criticism now which more or less will take the place of the previous criticism of American interest rate policy - namely that one is suggesting to the Americans they should alter their fiscal/monetary policy-mix, that is to say less budgetary deficit in order to alleviate the burden on monetary policy. Now here again, the Americans have a good answer and they can easily turn around this criticism in the following way: first, they can say that the American public sector deficit as a proportion of their gross national product which is at present about 2 per cent, is much lower than for instance in Germany and some other countries ; second they could say We Americans are already doing a great deal in order to cut the budget deficit, but what are you doing? and this is something which I think especially the German critics could not easily answer because they are only beginning now to change our fiscal policy in Germany and they are very much behind with it. So the Americans could say : If you complain about high interest rates, the first thing to do would be to change your own fiscal policy, which, of course, would also improve your balance of payments and therefore there would be less pressure on your interest rates.

Here I come back to what I said at the beginning, namely that the French Finance Minister said, this increase in the dollar exchange rate is like a third oil-shock. The Americans could easily reply: It's in your own hand, whether your currencies go so much down and the dollar so much up. So I don't think that very much will come out of that discussion except that one should look more closely into one's own business. So I think we will for the present time have to live with great uncertainties and volatilities. But in the medium term, I foresee a clear tendency towards more stabilisation and I would conclude with a well-know American saying : As hope springs eternal, let us continue to hope. 